\title{
Influence of School Environment on the Academic Performance of Secondary School Students in Akoko South West Local Government Area of Ondo State
}

\section{| Olowolabi Segun |}

\author{
Department of Guidance and \\ Counselling Faculty of \\ Education Adekunle Ajasin \\ University, Akungba-Akoko, \\ Ondo State, Nigeria
}

olowolabisegun@gmail.com

\begin{abstract}
Being accepted as out of the four essential language skills in the language learning process, writing seems to be difficult for numerous EFL learners. This research is an endeavor to explore if learners can grow out of the writing difficulties with topic-based writing activity. 78 third-year students at the Faculty of Foreign Languages of Phan Thiet University in Phan Thiet City, Binh Thuan Province participated in the study. These students were in the two writing classes, one class was treated as the experimental group (EG) and the other as the control group (CG). Research findings exposed the benefits of topic-based writing activity in nurturing learners' writing motivation and enhancing their writing skill. Furthermore, this activity gave students good chances to widen their knowledge on the topic, enrich their emotion on disadvantaged people, and build a friendly learning environment outside the classroom. The necessity and usefulness of the application of topic-based writing activity was predominantly recognized among students.

KEYWORDS

Influence; school environment; academic performance; secondary school; students
\end{abstract}

\section{INTRODUCTION}

Generally in the whole world, particularly in Nigeria, education has been considered to be corner-stone for development. It forms the basis for literacy, skills acquisition, technological advancement and ability to harness human and material resources toward the achievement of social goal (Fatola, 2015).

Adekunle (2012) reviewed education as the totality of all processes by which a child or young adult develops the ability, attitudes and other forms of behavior which are of positive value to the society in which he lives in. Education is very important in any given society. It is a process by which ability and capability of individuals are developed. Their ability might be physical ability, emotional, ability, social ability and intellectual ability. Emoruwa (2014) citing Kenneth see education as a process by which any society through schools, college, university and other Institution deliberately transmits knowledge, values and skills from one person to another.

Environment can be reviewed as a system within which living organism interact with physical element while education environment is a learning place where the learner learn and interact with learning facilities in order to be socialized and face the challenges in the society Adeola (2015) sees environment as consisting of all element existing around man and which exert some influence on him, These include physical, biological and social attributes. School environment can then be seen to include material and human resources, a learning place which consist of the entire interaction, The learning environment is the natural and provided setting where teaching and learning takes place. 
The school environment which include classroom, libraries, technical workshop, laboratory, teacher quality, school management, teaching method and peers etc are variable that affect student academic performance. The quality of education not only depend on the teacher but reflected in the performance of their duties and also in the effective coordination of the school environment (Adekunle 2012).

The issue of poor academic performance of students in Nigeria has been of much concern to the government,parent,teacher and even students themselves. Hence the school environment remains an important area that should be studied and well managed to enhance student academic performance. According to Ajewole and Omoegun (2013), a number of factors are said to have contributed to the students poor academic achievement in school, These factor may include: poor study habits and lack of availability of material resources, poor school climate, indiscipline, inadequate facilities, teacher ineffectiveness, the teacher method and the type of learning environment available for both the students and the teachers.

School environment may have negative influence on student academic achievement especially if such environment lack good school climate, instructional materials, discipline, physical facilities, high teacher quality, types of location of school, small class size and less population of student in the classroom, The school facilities are potent factors to qualitative education. The importance to teaching and learning of the provision of adequate instructional facilities for education cannot be over emphasized. The dictum that teaching is inseperable from learning but learning is seperable from teaching, is that teacher does the teaching to make the student learn but student can learn without the teacher. According to Akintola (2014), learning can occur through one's interaction with the environment. Environment here refers to facilities that are available to facilitate students learning outcome. The school environment is of paramount importance in shaping and reshaping intellectual ability. However supportive and favorable school environment which with enough learning facilities and favorable climate make student more comfortable, more concentrated on their academic activities that results in high academic performance.

A proper and adequate environment is very much necessary for fruitful learning of the child, the child spend most of his time in school, and thus school environment has exciting influence on performance through curriculum, teaching techniques and relationship Lawrence (2012), Adebayo (2015) maintain that the learning environment played a vital role in determining how student perform or respond to circumstance and situation around them, This implies that no society is void of environmental influence. The learning environment determines to a large extent how a student behaves and interact. it is today that the environment in which we find ourselves tend to mould our behavior so as to meet the demand of life whether negative or positive. In Nigeria there is an increase in the number of student enrolment in school with little or no regard to improve the learning environment so as to better their performance, Adebayo (2018) opined that an improved environment condition lead to higher intelligence score while poor environment condition reduces these scores, Academic achievement in this context simply means the scores student have obtained in either examination or test, which has led to their performance.

Kolade (2015) asserted that some of the notable factors that may influence student academic achievement in secondary school are: school climate, instructional material, discipline, physical facilities, teacher quality, type of location of school and class size, This is because school with good and conducive environment and physical facilities will produce better school leaver with high achievement, It is now certain that most of secondary school products cannot gain admission into federal universities or university of their choice due to poor performance in the placement examination into these schools. This 
poor performance may be attributed to poor learning environment especially in the following areas: school building, library service, school location, availability of trained teachers, provision of instructional material, motivation of teacher and school facilities.

\section{School Building}

These are tangible structure which serves as shelter for educational activities, they include among other classrooms, laboratory, workshop and teacher common room or offices, reading room, libraries, dormitories and dining hall. Despite the evidence that the quality of a school building affect student academic achievement, most public school in AKOKO SOUTH WEST are in poor physical condition, it is in line with thus that earthman (2014) opined that the building in which student spend a good deal of learning does influence how well they learn.

\section{School Location}

A school could be located in the urban or rural area. Rural schools are generally inferior to urban schools as schools in rural areas lacked human and material resources needed for success at school, the location of school whether urban or rural affects a child ability to study and perform at the level expected of him. Mayowa (2012) noted that different aspect of school environment(rural and urban) influence student achievement, she further stated that the individual student's academic behavior is influenced not only by the motivating force of his home, scholastic ability and academic value but also by social pressure applied by the participant in the school setting. As stated by Imoleayo (2012) in Akinjo and Ifeoluwa (2014) that because of urban involvement, student in urban schools perform better than those in rural school in language learning, the reason he gave the fact that rural student have limited access to reading materials, inadequate reading culture and insufficient graduate teacher in rural schools. Therefore, the location of school has tremendous influence on children academic achievement, in a situation whereby the school is sited in any area like airport, where such activities disrupt the teaching and learning of the student, one will not expect such student in this area to be doing well academically. Onukwo (2014) in his note says that a conducive environment enhanced a child's growth and development.

Most of the time parents of student are not satisfied with the facilities provided in their school. Also the extent to which some teacher exhibit high level of indiscipline does not seem to portray them as role models. PSA(2014) indicated that student achievement is more heavily influence by teacher quality than student race, class, prior academic record or school a student attend, the benefit being taught by good teachers are cumulative. Researcher indicated that the achievement gap widens each year between student with most effective teacher and those with less effective teacher, it suggests that the most significant gains in student achievement will likely be realized when student receive instruction from the good teacher over consecutive years. Lack of good teacher is the major contributor to the achievement gap, they rather encourage indiscipline among student by their attitude, thus may have negative influence on student academic achievement

\section{School Facilities}

School facilities refer to input which ease the operation of academic achievement. They include desk, chair, and blackboard, dustbin, teaching aid, type writers, computer generator and calculator and so on .School facilities according to Ehiametalor (2014) are operational inputs of every instructional programmer. They are material that facilitate effective 
teaching and learning in schools. The quality and quantity of school facilities enhance the quality of teaching and learning as well as effective school management (Ojedele 2013).

Furthermore, education facilities are needed to develop cognitive areas of knowledge, ability and skills that are necessary for academic achievement. Moreover, the development of the effective psychomotor domain is also facilitated by the presence of necessary and relevant school facilities.

This problem of poor performance is more pronounce to ill-equipped school hence it become necessary to find out the influence of school environment on the academic achievement of students of public secondary schools of Akoko South West Local Government Area Of Ondo State, Nigeria.

The influence of school environment on academic achievement of student has been an issue of concern to all stakeholders in education. This is event in the rate of mass failure of student both internal and external examination as revealed by research studies. Several research studies have identified other factor such as school climate, instructional material, discipline and physical facilities, teacher quality, type of location of school, classroom and over population of student in classroom as being responsible for poor academic achievement of student.

The researcher has observed with dismay that the school environment in the study is nothing to write home about. The school climate is not interesting for teaching and learning, instructional material are inadequately provided, infrastructural facilities are in dilapidated condition, lack of trained teacher and other facilities that promotes teaching and learning are also in short fall which may tends to influence student academic performance in school.

The research questions were converted to hypothesis thus:

H01. School climate has no significant influence on academic achievement of secondary school student in Akoko South West Local Government Area Of Ondo State, Nigeria.

H02. Discipline of teachers has no significant influence on academic achievement of secondary school students.

HO3. School physical facilities has no significant influence on academic achievement if secondary school students.

\section{RESEARCH METHODS}

\section{Research Design}

A descriptive research design of the survey type was used which involves the use of questionnaire to get the information required.

\section{Population}

The population comprised of all the secondary school students in Akoko South West Local Government Area of Ondo State, Nigeria.

\section{Sample and Sampling Technique}

A sample of two hundred students was used for this study. Simple random sampling technique was used in selecting two hundred (200) students in six schools in Akoko South West Local Government Area of Ondo State, Nigeria.

\section{Research Instrument}

The instrument use for this research is questionnaire. Title Influence of school environment on academic achievement questionnaire (TISEQ). The instruments was design by the researcher,it consist of 15 item structure. The part A consist of introductory section while the part $\mathrm{B}$ centered on the request for the respondents to complete the questionnaire meant 
to answer the research questions proposed for the study. The items of the question would be responded to Likert type scale of Strongly Agree (SA), Agree(A), Disagree(D), and Strongly Disagree(SD) respectively.

\section{Data Analysis}

The data obtained through the questionnaire was scored and used by the researcher,chisquare statistics was used in testing the three null hypotheses formulated at 0.05 level of significance

\section{RESULTS AND DISCUSSION}

\section{Research Hypothesis One}

School climate has no significant influence on academic achievement of secondary school students.

Table 1. Chi-square $\left(\mathrm{x}^{2}\right)$ test of influence of school climate on academic achievement of secondary school students.

\begin{tabular}{|l|l|l|l|l|l|l|l|}
\hline Preference & $\begin{array}{l}\text { Observed } \\
\text { Frequency }\end{array}$ & $\begin{array}{l}\text { Expected } \\
\text { Frequency }\end{array}$ & Df & $\begin{array}{l}\mathrm{X}^{2}- \\
\text { cal }\end{array}$ & $\begin{array}{l}\mathrm{X}^{2}- \\
\text { tab }\end{array}$ & Level & Decision \\
\hline Influence & 150 & 100 & 2 & 33.43 & 21.03 & 0.05 & Rejected \\
\hline No Influence & 50 & 100 & & & & & \\
\hline
\end{tabular}

The table 1 show that the chi-square calculated value of 33.43 is greater than the chisquare tabulated value of 21.03 at 0.05 level of significance and $\mathrm{df}=2$. Thus, the null hypothesis is rejected which stated that school climate has no significant influence on academic achievement of secondary school students. This implies that school climate has significant influence on academic achievement of secondary school students.

\section{Research Hypothesis Two}

Discipline of teacher has no significant influence on academic achievement of secondary school students.

Table 2. Chi-square $\left(\mathrm{x}^{2}\right)$ test of influence of teacher discipline on academic achievement of secondary school students.

\begin{tabular}{|l|l|l|l|l|l|l|l|}
\hline Preference & $\begin{array}{l}\text { Observed } \\
\text { Frequency }\end{array}$ & $\begin{array}{l}\text { Expected } \\
\text { Frequency }\end{array}$ & Df & $\begin{array}{l}\mathrm{X}^{2}- \\
\text { cal }\end{array}$ & $\begin{array}{l}\mathrm{X}^{2}- \\
\text { tab }\end{array}$ & Level & Decision \\
\hline Influence & 154 & 100 & 12 & 55.9 & 21.03 & 0.05 & Rejected \\
\hline No Influence & 46 & 100 & & & & & \\
\hline
\end{tabular}

Table 2 shows that the chi-square calculated value of 55.9 is greater than chi-square tabulated value of 21.03 tested at 0.05 level of significant and $\mathrm{df}=2$. Thus, the null hypothesis that stated that discipline of teacher has no significant influence on academic achievement of secondary school students is rejected. This implies that discipline of teacher has significant influence on academic achievement of secondary school students.

\section{Research Hypothesis Three}

School physical facilities have no significant influence on academic achievement of secondary school students.

Table 3. Chi-square $\left(x^{2}\right)$ test of influence of school physical facilities on academic achievement secondary school students.

\begin{tabular}{|l|l|l|l|l|l|l|l|}
\hline Preference & $\begin{array}{l}\text { Observed } \\
\text { Frequency }\end{array}$ & $\begin{array}{l}\text { Expected } \\
\text { Frequency }\end{array}$ & Df & $\begin{array}{l}\mathrm{X}^{2}- \\
\text { cal }\end{array}$ & $\begin{array}{l}\mathrm{X}^{2}- \\
\text { tab }\end{array}$ & $\begin{array}{l}\text { Level of } \\
\text { Significance }\end{array}$ & Decision \\
\hline Influence & 164 & 100 & 2 & 20.8 & 21.03 & 0.05 & Accepted \\
\hline No Influence & 36 & 100 & & & & & \\
\hline
\end{tabular}


Table 3 shows that the chi-square calculated value of 20.8 is less than the chi-square tabulated value of 21.03 tested at 0.05 level of significant and $\mathrm{df}=2$. Thus, the null hypothesis is accepted. This implies that a School physical facility has no significant influence on academic achievement of secondary school students.

\section{Discussion}

The study revealed that school climate has significant influence on academic achievement of secondary school students in Akoko South West Local Government Area of Ondo State. This findings supported the findings of Kolawole (2018), who found that student who attended school with a more positive climate tend to have more positive attitude towards school and school subject which lead to higher achievement. It also supported Mobolaji (2017); whose research on school climate in high risk urban environment indicates that a positive, supportive and culturally conscious school climate can significantly shape the degree of academic success experienced by urban students

Secondly, the study revealed that discipline of teacher has significantly influence on academic achievement of secondary school students. The finding supported Wright, Horn and Solomon (2016) who claimed that teacher is an important factor influencing student learning. The finding agreed with the findings of Oke (2018) that indiscipline among teacher including absenteeism from school, lateness, non-preparation of lesson notes, illegal collection from parent and student, drug taking and sexual immorality are serious threat to students academic performance. In line with this, Perkins (2013) indicated that teacher attitude contributed significantly to students attention in classroom and performance.

The Third finding revealed that a school physical facility has no significant influence on academic achievement of secondary school students. This finding disagreed with the finding of Fabunmi (2016) who asserted that school facilities when provided will aid teaching and learning programme and consequently improve academic achievement of students. Absent or poor quality of educational facilities can affect academic performance. This finding disagreed with Howard (2015) who argued that facilities formed one of the potent factors that contribute to academic achievement in the school system.

\section{CONCLUSION}

Based on the finding of the study, it was concluded that school climate, discipline and physical facilities have significant influence on academic achievement of secondary school student in Akoko South West Local Government Area of Ondo State, Nigeria.

\section{Recommendations}

Based on the findings of this study, the following recommendations were made:

- School authorities should provide a conducive school environment that has good climate for effective teaching and learning. When Environment is safe and students are treated fairly by teachers, they are happy to be in school as well as feel they are part of the school.

- Effective school discipline should be encouraged by head teacher in controlling teacher's behavior which are capable of jeopardizing students' academic achievement in schools.

- Current teaching or learning materials should be made available to schools to help teachers performance in the quest for best academic achievement of students in the schools. 


\section{REFERENCES}

Abebayo N.A. (2015). Toward meeting science and technology manpower Development for national development in Lyam, Y.A.

Adeola, P.S. (2015). Introduction to school management, administration and supervision. Makurdi,Hilton Press.

Adekunle (2012). "Achievement and Ability Tests the Domain", Educational measurement.

Ajewole, S. (2013). What is Education Planning;?

Adesina, S. (Ed) Introduction to Educational Planning Academic Achievement of Secondary School Student University of Ile Ife.

Akintola ,O.M. (2014). Science Teachers 130). Jos: HEBN Hints on teaching practice and general principles of education. Lagos,OSKO Associates.

Akinjo, E.I.(2014). Psychology of learning. Basic concepts and Application.

Earthman, G.I. (2014). Prioritization of 31 Criteria for School Building Adequacy.American Civil Liberties Union Foundation of Mary Land. Accessed Online on http:www.ac/u.md.org/atop\%20issues/education\%reform/earthfinal10504.

Ehimetalor (2014) in Nwagwu, N.A. et al(ed) (2014). Current issues In Educational Management in Nigeria, Benin Ambik Press, p 305.

Emoruwa. (2014). Promoting physical activity among children and adolescents: The strengths and limitations of school based approaches. Lagos State, Oakland Press.

Fabunmi , M. (2016). Differential allocation of educational resourcesand Secondary school academic performance in Edo State, Nigeria University of Ibadan.

Fatola, J. G. (2015). An unpublished Ph.D. Thesis, resources concentration, Utilization and management as correlates of students learning Outcomes: a study in School Quality in Oyo State Unpublished Ph.D. Thesis, university of Ibadan.

Howard, F.O. (2015) "The road to open and healthy school". Lagos, Collins Nigeria Ltd.

Imoleayo, J. A. (2012). 30, 5264. Investing in the Future: Setting educational Priorities in the developing world TEP and Pergonion Press.

Kolade, F. O. (2015). strah v solo, srah pred solo fear of school,fear in school.

Kolawole, S. O. (2018). Youth and violence;theoretical concept and Pedagogical

Lawrence, A.S.A. (2012) "School Environment and Academic Achievement of Standard IX Students" Journal of Educational a Instructional Studies in the World 2(3), August Pp. 210215.5051.

Mayowa, R. (2012).Managing international distribution channel A cross cultural approach. Marketing Channel, 17(2), 89 National Association of State Boar117. Journal of ds of Education. (1994) Schools without fear: The report of the NASBE study Group on violence and its impact on schools and learning.

Mobolaji, L. M. (2017). Examining school climate: Defining factors and education.

Ojedele M. B. (2013). progress and problem in Nigeria secondary school 1960_1984. Journal of research in curriculum.

Oke, D.O. (2018) supervision and quality of teaching personnel effect on student academic performance education research and review.

Onukwo B.S. (2014).Teaching in Nigeria. The bureaucracy of professionalism $2^{\text {nd }}$ Edition. Port Harcourt: Mercury International Publishing Nigeria.

Perkins, K. (2013). The secondary school Principal: manager and supervisor. Newton: Ally.

PSA. (2014). Facilities Provision and Management for Successful Implementation of the Universal Basic Education (UBE) Programme in Nigeria. A Paper Presented at the Annual Nation Conference of NAEAP held at University of Ibadan, $29^{\text {th }}-31^{\text {st }}$ October.

Solomon E.A (2016). Discipline and academic performance.International Journal of academic research in progressive education and development. 